Syntax Literate : Jurnal Ilmiah Indonesia p-ISSN: 2541-0849

e-ISSN : 2548-1398

Vol. 6, No. 1 Januari 2021

\title{
GAMBARAN REWARD SYSTEM: EXTRINSIC DAN INTRINSIC KARYAWAN DI PT INDUSTRI KERETA API PERSERO MADIUN
}

\author{
Alief Ikhtiar Wicaksono dan Ika Adita Silviandari \\ Universitas Airlangga Surabaya dan Universitas Brawijaya Malang \\ Email: alief.ikhtiar.wicaksono-2018@pasca.unair.ac.id dan Ikaaditas@gmail.com
}

\begin{abstract}
One of the largest manufacturing companies in ASEAN, PT INKA needs adequate human resources. Human resources have an important role in the running of an organization. Efforts to maintain the performance of human resources are stable or increase, it is necessary to have a movement from the company that is carried out in a real way and has an impact that can improve employee performance. A reward is one of the factors that can improve employee performance. This study aims to obtain an overview of PT Kereta Api Indonesia (Persero) Madiun. Researchers used direct and semi-structured interview methods. The subject of the first interview was the manager of human and organizational development and the subject of the second interview was the payroll staff. The researcher also conducted a documentation study, namely the 2002 INKA SK and the PT INKA company profile. The results of this study show that PT INKA's intrinsic reward is manifested in the form of the Most Valuable Employee, which is given annually and given to employees who have standards that exceed those set by PT INKA. PT INKA's extrinsic rewards are transport allowances, holiday allowances, education allowances, job allowances, promotions and incentives
\end{abstract}

Keywords: extrinsic; intrinsic; PT INKA; reward; system

\section{Abstrak}

Salah satu perusahan manufaktur terbesar di ASEAN, PT INKA membutuhkan sumber daya manusia. Sumber daya manusia memiliki peranan penting dalam berjalannya suatu organisasi. Usaha menjaga supaya kinerja sumber daya manusia tersebut stabil atau meningkat, maka dibutuhkanlah suatu pergerakan dari perusahaan tersebut yang dilakukan secara nyata dan memberikan dampak yang dapat meningkatkan kinerja karyawan. Reward adalah salah satu faktor yang dapat meningkatkan kinerja karyawan. Penelitian ini bertujuan untuk mendapatkan gambaran reward system yang ada di PT Kereta Api Indonesia (Persero) Madiun. Peneliti menggunakan metode wawancara secara langsung dan semi terstruktur. Subjek wawancara pertama adalah manager pengembangan sumber daya manusia dan organisasi dan subjek wawancara kedua adalah staff penggajian. Peneliti juga melakukan studi dokumentasi yaitu SK INKA Tahun 2002 dan company profile PT INKA. Hasil dari penelitian ini didapatkan bahwa intrinsic reward PT INKA diwujudkan dalam bentuk Most Valuable Employee yang diberikan setiap tahun dan diberikan kepada karyawan yang mempunyai standar melebihi yang sudah 
ditetapkan oleh PT INKA. Extrinsic reward PT INKA adalah tunjangan transport, tunjangan hari raya, tunjangan pendidikan, tunjangan jabatan, promosi dan insentif.

Kata kunci: extrinsic; intrinsic; PT INKA; reward; system.

\section{Coresponden Author}

Email: alief.ikhtiar.wicaksono-2018@pasca.unair.ac.id Artikel dengan akses terbuka dibawah lisensi

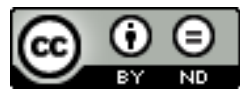

\section{Pendahuluan}

Kereta api merupakan salah satu alternatif alat transportasi yang diminati sebagian besar masyarakat Indonesia, terutama di Pulau Jawa. Hal ini disebabkan oleh jumlah kecelakaan yang terjadi relatif kecil dibanding dengan angkutan umum lainnya. Selain itu, waktu perjalanan juga lebih efektif dan efisien karena faktor kemacetan lalu lintas dinilai relatif kecil. Peningkatan sarana dan prasarana pada angkutan kereta api dilakukan dengan harapan masyarakat dapat semakin banyak yang menggunakan jasa kereta api sehingga kapasitas lalu lintas perjalanan kereta api meningkat.

Perusahaan milik negara yang bertanggungjawab dalam industri kereta api di Indonesia adalah PT Industri Kereta Api Indonesia (INKA). PT INKA terletak di Jalan Yos Sudarso No. 17 di Madiun, Jawa Timur. PT INKA didirikan pada 18 Mei 1981. INKA adalah perusahaan terbesar di Asia Tenggara dalam bidang industri kereta api. INKA sendiri sudah bekerja sama dengan beberapa negara baik di kawasan Asia maupun di kawasan Eropa. Produk yang dihasilkan diantaranya adalah lokomotif, kereta penumpang dan kereta barang.

PT INKA terdiri atas beberapa divisi, baik divisi yang langsung berhubungan dengan bagian produksi maupun yang tidak langsung dengan produksi. Divisi yang langsung berhubungan produksi diantaranya adalah divisi fabrikasi, divisi finishing, dan divisi perencanaan dan pengendalian produksi. Sedangkan divisi yang tidak berhubungan langsung dengan produksi adalah divisi perencanaan perusahaan, general affairs, divisi keuangan dan divisi sumber daya alam.

Salah satu perusahan manufaktur terbesar di ASEAN, PT INKA membutuhkan sumber daya manusia yang memadahi. Sumber daya manusia memiliki peranan penting dalam berjalannya suatu organisasi. PT INKA memiliki berbagai macam divisi, sehingga dibutuhkan sumber daya manusia yang mempunyai kompetensi sesuai dengan divisi yang ada. Hal tersebut mengharuskan pihak perusahaan untuk berhati-hati dan menjaga kualitas dari setiap sumber daya manusia yang bekerja di setiap divisi tersebut.

Seperti yang dikatakan oleh Snyder "Manusia merupakan sumber daya yang bernilai, dan ilmu perilaku menyiapkan hanya teknik dan program yang dapat menuntun pemanfaatan sumber daya manusia secara lebih efektif."

Usaha menjaga supaya kinerja sumber daya manusia tersebut stabil atau meningkat, maka dibutuhkanlah suatu pergerakan dari perusahaan tersebut yang 
dilakukan secara nyata dan memberikan dampak yang dapat meningkatkan kinerja karyawan. Penghargaan dan motivasi telah dipandang sebagai instrumen yang sangat penting dalam kinerja karyawan (Prabu \& Wijayanti, 2016). Dengan memberikan reward yang menjadi bagian dari kebijakan perusahaan yang telah ditentukan sebelumnya berguna untuk meningkatkan kinerja karyawan dan produktivitas perusahaan (Gohari et al., 2013). Reward adalah gaji/upah, bonus, tunjangan, promosi, pengakuan, kemajuan karir, tanggung jawab dan kesempatan belajar yang bertujuan untuk memotivasi karyawan agar bekerja dengan lebih baik sehingga dapat meningkatkan produktivitas atau kinerjanya (Edirisooriya, 2014).

Reward dapat dibagi ke dalam dua kategori, yaitu penghargaan intrinsik dan penghargaan ekstrinsik (Mulyadi \& Setyawan, 2001). Penghargaan intrinsik berupa rasa puas diri yang diperoleh seseorang yang telah berhasil menyelesaikan pekerjaannya dengan baik dan telah mencapai sasaran tertentu. Untuk meningkatkan penghargaan intrinsik, manajemen dapat menggunakan berbagai cara seperti penambahan tanggungjawab, pertisipasi dalam pengambilan keputusan dan cara lain yang meningkatkan harga diri seseorang dan mendorong seseorang untuk menjadi lebih baik. Penghargaan ekstrinsik terdiri dari kompensasi yang diberikan kepada personel, baik yang berupa kompensasi langsung seperti upah, pembagian bonus dan lain-lain. Ekstrinsik reward adalah biasanya berupa financial atau reward berwujud yang dimana termasuk pembayaran, promosi, interpersonal reward, bonus dan benefit (Hafiza, Shah, Jamsheed, \& Zaman, 2011). Sedangkan kompensasi non-moneter seperti asuransi kecelakaan, asuransi hari tua dan honorarium liburan. Penghargaan non-moneter dapat berupa sesuatu yang secara ekstra diberikan perusahaan seperti ruang kerja yang memiliki fasilitas istimewa.

Sesuai dengan teori di atas, PT INKA mempunyai beberapa penghargaan, salah satunya adalah Most Valuable Employee atau karyawan terbaik dalam tahun tersebut yang termasuk dalam penghargaan intrisik. Untuk menjadi Most Valuable Employee, diwajibkan bagi karyawan untuk mendapatkan nilai yang tinggi dari tiga penilaian yang ada di INKA, yaitu penilaian kinerja, penilaian perilaku karyawan dan penilaian kedisiplinan karyawan. Penilaian ini dilaksanakan setiap enam bulan sekali dan yang memberikan penilaian adalah atasan dari karyawan tersebut. Hadiah yang didapat dari Most Valuable Employee bisa berupa sejumlah nominal uang atau jalan-jalan ke luar negeri, tergantung dari kebijakan perusahan. Selain itu, juga ada penghargaan ekstrinsik yang berasal dari lamanya seseorang mengabdi di PT INKA dan juga dari prestasi seorang karyawan.

Manfaat reward, atau penghargaan ada 2 macam, yaitu memberikan informasi dan memberikan loyal (Mulyadi \& Setyawan, 2001). Salah satu yang mendapatkan perhatian yang besar adalah reward terhadap kenyataan bahwa mayoritas karyawan memiliki tanggung jawab atas pekerjaan yang telah dilakukannya dan keluarga, serta pada saat organisasi memberikan bantuan untuk menangani kewajiban dalam pekerjaannya, loyalitas dari para pekerja pun juga akan mengalami peningkatan (Luthan, 2011). Pekerja yang mempunyai loyalitas terlibat dalam tujuan perusahaan, 
bertindak sesuai dengan kesejahteraan jangka panjang perusahaan, dan tidak mencari pekerjaan alternatif atau menanggapi tawaran luar bahkan ketika ditawarkan gaji sedikit lebih tinggi. Tenaga kerja yang setia akan mengurangi biaya perputaran tenaga kerja (Abdullah, Musa, Zahari, Rahman, \& Khalid, 2011). Manfaat reward dengan maksud memberikan informasi adalah reward tersebut dapat menarik perhatian dari setiap karyawan dan mengingatkan kepada karyawan tentang pentingnya tugas dan tanggungjawab mereka dibandingkan dengan hal lain. Reward juga dapat meningkatkan motivasi karyawan terhadap kinerja mereka sehingga membantu mereka untuk memutuskan bagaimana mereka membagi waktu dan usaha mereka. Semakin tinggi motivasi kerja akan berpengaruh pada peningkatan kinerja karyawan. Dengan diberikannya motivasi pada setiap karyawan, diharapkan setiap individu akan bekerja lebih keras lagi dan lebih antusias untuk menyelesaikan tugasnya demi mencapai kinerja yang maksimal (Damayanti, Susilaningsih, \& Sumaryati, 2013).

Sistem penghargaan merupakan salah satu alat pengendali penting yang digunakan oleh perusahaan untuk memotivasi personelnya agar mencapai tujuan perusahaan (bukan tujuan personel secara individu) dengan perilaku sesuai dengan yang diharapkan oleh perusahaan (bukan perilaku yang disukai oleh personel secara pribadi) (Mulyadi \& Setyawan, 2001). Sistem reward adalah alat penting yang dapat digunakan manajemen untuk memberikan motivasi kepada karyawan dalam bekerja. Dengan kata lain, sistem reward digunakan untuk menarik semangat bekerja dan memotivasi bekerja lebih baik lagi bagi seluruh anggota organisasi dalam (Pratheepkanth, 2011). Reward system erat kaitannya dengan motivasi kerja karyawan sehingga mereka terpacu untuk bekerja memenuhi tujuan dari organisasi tersebut. Motivasi kerja adalah kemampuan untuk mengubah perilaku seseorang, di mana motivasi merupakan dorongan untuk bertindak, karena perilaku manusia diarahkan menuju tujuan yang sama (Güngör, 2011). Motivasi intrinsik dan motivasi ekstrinsik berpengaruh secara positif dan signifikan terhadap kinerja karyawan (Akbar, 2012).

Penghargaan atau reward untuk tim juga diperlukan dalam suatu organisasi. Penghargaan ini bertujuan untuk meningkatkan kinerja suatu unit kera dalam suatu organisasi. Penghargaan atau reward merupakan elemen penting untuk memotivasi kinerja karyawan untuk berkontribusi menuangkan ide inovasi yang paling baik untuk fungsi bisnis yang lebih baik dan meningkatkan kinerja perusahaan baik secara financial dan non-financial (Wirawan \& Afani, 2018). Permasalahan yang sering terjadi dalam penghargaan tim adalah keadilan. Dalam sebuah tim, tentu ada beberapa karyawan yang mempunyai kontribusi lebih daripada rekan-rekan yang lain. Akan tetapi, karena bentuk penghargaan ini adalah penghargaan tim, makan semua karyawan tersebut akan mendapatkan reward yang sama. Kebanyakan organisasi menggunakan penghargaan tim sebagai reward yang tidak tetap namun lebih tinggi dari gaji pokok. Untuk kompensasi individu, dapat didasarkan kepada kompetensi individu atau keterampilan individu. Penghargaan tim biasanya diberikan secara tahunan dalam jumlah tertentu.

Pada penelitian terdahulu yang dilakukan oleh (Koencoro, 2013) menghasilkan bahwa reward dan punishment berpengaruh terhadap kinerja karyawan. Pada penelitian 
yang dilakukan oleh (Koencoro, 2013) tidak memberikan gambaran reward yang diberikan oleh PT INKA. Maka, dalam pembaruan penelitian kali ini, peneliti melakukan penelitian tentang gambaran reward system yang ada di PT INKA. Manfaat dari penelitian ini adalah nantinya perusahaan dapat meninjau dan mengevaluasi reward system yang sudah ada. Tujuan penelitian ini adalah peneliti mencari informasi tentang reward system yang ada di PT INKA dengan cara melakukan wawancara terhadap narasumber dan mempelajari dokumen-dokumen pendukungnya.

Karyawan dapat mendapatkan suatu penghargaan dalam bentuk bonus. Bonus sendiri biasanya berupa sekali upah dan tidak termasuk pada upah pokok. Sebelumnya, bonus berupa sekali upah ini hanya ada di kalangan tingkat eksekutif. Namun, selanjutnya bonus ini telah menyebar di tingkat-tingkat selain eksekutif. Bonus biasanya digunakan untuk memacu supaya karyawan-karyawan dapat menyubnagkan ide-ide yang bagus atau meningkatkan ketrampilan mereka. Bonus akan keluar jika seorang karyawan dapat melakukan kinerja di atas standar yang sudah ditentukan. Sebaliknya, bonus tidak akan turun jika karyawan tersebut mempunyai kinerja di bawah standar yang sudah ditentukan.

Penghargaan insentif yang paling sering digunakan adalah uang tunai karena dapat digunakan untuk membeli apapun. Selain itu, penghargaan berupa pengakuan juga sering digunakan. Misalnya adalah penghargaan untuk karyawan terbaik pada bulan tersebut atau penghargaan untuk karyawan terbaik dalam tahun tersebut. Penghargaan atas pengabdian juga sering digunakan. Pengabdian ini diberikan dengan melihat berapa lama seorang karyawan tersebut mengabdikan diri pada organisasi.

\section{Metode Penelitian}

Metode pengambilan data yang pertama adalah wawancara. Wawancara yang dilakukan penulis adalah wawancara secara langsung dan semi terstruktur. Sebelum melakukan wawancara, penulis membuat guideline dahulu dahulu supaya tidak melebar dari pokok pembahasan. Wawancara dilakukan penulis terhadap 2 subjek. Untuk subjek pertama, penulis melakukan wawancara sebanyak dua kali. Subjek pertama penulis adalah manager pengembangan sumber daya manusia dan organisasi. Subjek kedua penulis menjabat sebagai staff pratama bagian penggajian.

Selain wawancara, peneliti juga melakukan pengambilan data dengan studi dokumentasi yang berkaitan dengan reward system yang ada di PT INKA. Dokumendokumen tersebut tidak diizinkan untuk digandakan karena merupakan dokumen penting sehinga dokumen tersebut hanya boleh dipelajari saja. Dokumentasi yang dipelajari oleh penulis adalah SK INKA Tahun 2002 yang berkaitan dengan penghargaan. Selain itu, peneliti juga mempelajari company profile yang diberikan oleh PT INKA dalam bentuk softfile.

\section{Hasil dan Pembahasan}

Reward yang dirasakan merupakan penilaian evaluatif yang berupa manfaat finansial dan non-finansial yang diterima tenaga kerja hasil dari kinerjanya dengan 
perusahaan (Newman \& Sheikh, 2012). Sistem reward merupakan bentuk penghargaan yang disediakan dan dikontrol oleh perusahaan, tetapi belum pasti menguntungkan dari segi moneter bagi karyawan tersebut (Bustamam, Teng, \& Abdullah, 2014). Reward system berbasis kinerja mendorong personel untuk mengubah kecenderungan mereka dari semangat untuk memenuhi kepentingan sendiri ke semangat untuk memenuhi tujuan organisasi (Mulyadi \& Setyawan, 2001). Sistem penghargaan (reward system) terdiri atas semua komponen organisasi, termasuk orang-orang, proses, aturan dan prosedur, serta kegiatan pengambilan keputusan, yang terlibat dalam mengalokasikan kompensasi dan tunjangan kepada pegawai sebagai imbalan untuk kontribusi mereka pada organisasi (Moorhead \& Griffin, 2013). Reward system yang ada di PT INKA mempertimbangkan tiga aspek, yaitu penilaian kinerja, penilaian perilaku dan penilaian dalam bidang kedisiplinan. Dalam pendekatan reward system dari (Byars, L. L., \& Rue, 2004), terdapat dua tipe reward, yaitu intrinsic reward dan extrinsic reward. Intrinsic reward dan extrinsic reward yang ada di PT INKA akan dijelaskan di bawah ini:

1. Intrinsic Reward

Pertama, intrinsic reward di PT INKA adalah Most Valuable Employee. Reward ini diberikan untuk mengapresiasi karyawan-karyawan yang mempunyai standar lebih. Reward ini bukan suatu kebijakan yang harus ada setiap tahun tapi suatu yang bentuknya inisiatif. Most Valuable Employee dilihat dari penilaian karyawan, penilaian kinerja dan data kedisiplinan. Rencana dari reward untuk Most Valuable Employee adalah jalan-jalan ke luar negeri. Untuk destinasinya sendiri adalah ke perusahaan manufaktur kereta api, dengan harapan saat karyawan yang menjadi Most Valuable Employee ini pulang, mereka akan membagikan pengalaman-pengalaman yang sudah mereka rasakan kepada karyawan lain. Rule dari Most Valuable Employee ini masih dalam tahap pembuatan. Most Valuable Employee sudah berjalan akan tetapi reward yang diberikan bukan berupa jalanjalan ke luar negeri tetapi berupa nominal uang. Implementasi Most Valuable Employee ini belum signifikan dirasakan karena konsepnya belum tersampaikan secara baik dan jelas. Dengan adanya reward ini, diharapkan dapat menciptakan lingkungan yang kompetitif dari tiap unit kerja.

Apabila dilihat dengan pendekatan reward system (Byars, L. L., \& Rue, 2004), Most Valuable Employee dapat masuk ke dalam achievement. Menurut Sadly (1977) achievement atau prestasi adalah hasil yang dicapai oleh tenaga atau daya kerja seseorang dalam waktu tertentu. Most Valuable Employee ini juga termasuk ke dalam extrinsic reward yaitu berupa formal recognition atau pengakuan secara formal. Most Valuable Employee ini diumumkan setiap enam bulan sekali pada saat upacara PT INKA atau pada saat perayaan ulang tahun PT INKA.

2. Extrinsic Reward

Extrinsic reward di PT INKA salah satunya adalah tunjangan transport yang dilihat berdasarkan kehadiran karyawan. Jika dia masuk kerja secara penuh, maka dia akan mendapatkan tunjangan secara penuh. Jika tidak, akan dipotong sesuai dengan hari tidak masuk kerja berdasarkan golongannya. 
Ada juga tunjangan hari raya. Besaran tunjangan hari raya sudah diatur oleh perusahaan. Tunjangan pendidikan ini masih berlaku dan sebenarnya untuk karyawan sendiri. Tunjangan ini keluar setiap jadwal penerimaan murid baru baik di sekolah atau universitas. Untuk yang sudah berkeluarga maupun belum, meraka akan tetap mendapatkan tunjangan ini. Tunjangan ini sudah diatur di SK. Jadi semisal akan diberikan satu kali upah, maka itu akan diberikan ke semua karyawan baik yang sudah berkeluarga maupun belum berkeluarga. Tunjangan pendidikan ini cair tiap tahun, seperti yang tertulis di PKB. Tunjangan-tunjangan di PT INKA jika melihat dari pendekatan reward system (Byars, L. L., \& Rue, 2004) termasuk dalam pay. Pay atau upah adalah bagian dari komponen upah disamping upah pokok (basic salary) dan pendapatan non-upah, seperti: fasilitas, bonus dana tau Tunjangan Hari Raya (Pasal 12 ayat 2 PP No. 8 Tahun 1981 dan SE Menteri Tenaga Kerja RI No. SE-07/Men/1990).

Untuk promosi, berkaitan dengan karir karyawan. Promosi diperoleh dari penilaia kinerja dan perilaku dengan beberapa syarat tertentu. Karyawan yang bisa dipromosikan minimal mempunyai penilaian kinerja di atas standar selama beberapa periode. Promosi dalam PT INKA jika dilihat dengan penekatan reward system (Byars, L. L., \& Rue, 2004) termasuk dalam promotion. Promotion menurut (Manullang, 2004) berarti kenaikan jabatan, yakni menerima kekuasaan dan tanggung jawab lebih besar dari kekuasaan dan tanggungjawab sebelumnya.

Dalam upah terdapat tunjangan jabatan. Jika karyawan tidak menjabat, maka tidak akan mendapatkan tunjangan jabatan. Besarnya sesuai dengan jabatan yang diduduki. Penggajian diatur dalam SK remunerasi. Tunjangan sendiri dalam pendekatan reward system (Byars, L. L., \& Rue, 2004) termasuk daam pay. Pay adalah bagian dari komponen upah disamping upah pokok (basic salary) dan pendapatan non-upah, seperti fasilitas, bonus dana tau tunjangan hari raya (lihat pasal 12 ayat 2 PP No. 8 Tahun 1981 dan SE Menteri Tenaga Kerja RI No. SE07/Men/1990).

Sistem penggajian di PT INKA standarnya ada tiga. Dalam upah, melihat golongan dan masa kerja. Insentif karya bisa berbeda dilihat dari prestasinya. Penilaian akan berlangsung enam bulan sekali, jika nilai turun makan akan mendapatkan insentif karya sedikit. Dalam pendekatan reward system (Byars, L. L., \& Rue, 2004), insentif termasuk dalam incentive payment. Menurut Andrew F Sikula (dalam buku Edy Soeryanto Soegito, 2009) insentif adalah sesuatu yang mendorong atau mempunya kecenderungan untuk merangsang suatu kegiatan, insentif adalah motif-motif dan imbalan-imbalan yang dibentuk untuk memparbiki produksi.

Dari intrinsic reward dan extrinsic reward di PT INKA yang sudah dijelaskan sebelumnya, menurut (Byars, L. L., \& Rue, 2004), intrinsic reward adalah reward yang bersifat internal kepada individu, berasal dari keterlibatan aktivitas tertentu atau tugas. Biasanya imbalan ini merupakan nilai positif atau rasa puas karyawan terhadap dirinya sendiri karena telah menyelesaikan tugas yang 
baginya cukup menantang. Teknik-teknik pemerkaryaan karyawan, seperti peran dalam pengambilan keputusan, tanggungjawab yang lebih besar, kebebasan dan keleluasaan kerja yang lebih besar dengan tujuan untuk meningkatkan harga diri karyawan, secara intrinsic merupakan imbalan bagi karyawan. Selain itu, rasa aman atau lingkungan kerja yang nyaman, pengembangan diri, fleksibilitas karir, peluang kenaikan penghasilan, symbol status, pujian dan pengakuan. Salah satu contohnya adalah tentang rasa aman. Ketika ada pemutusan kerja secara besar-besaran, para karyawan akan tidak merasa aman dalam menjalankan tugas dan kewajibannya. Untuk mengatasi hal ini, organisasi berusaha untuk menenangkan karyawannya dengan menawarkan rasa aman untuk tidak di putuskan hubungan kerjanya, akan tetapi karyawan tersebut tidak mendapat kenaikan imbalan uang. Kedua imbalan ekstrinsik dan intrinsik yang diharapkan akan positif terkait dengan kepuasan kerja, reward yang diharapkan akan lebih peduli untuk imbalan moneter daripada imbalan non-moneter (Linz \& Semykina, 2011).

Menurut (Byars, L. L., \& Rue, 2004), extrinsic reward adalah reward yang dikontrol dan didistribusikan secara langsung oleh organisasi dan merupakan reward yang berwujud.

Intrinsic reward dan extrinsic reward merupakan dua hal yang berbeda, namun keduanya saling berkaitan satu sama lain. Sebagai contohnya adalah seorang karyawan yang mendapatkan extrinsic reward berupa kenaikan gaji, hal tersebut sekaligus dapat dikatakan sebagai sebuah prestasi (intrinsic reward). Gaji, promosi, supervisi, pekerjaan itu sendiri, dan kondisi kerja memiliki pengaruh yang positif dan signifikan terhadap kinerja karyawan. Contoh tersebut dapat diartikan bahwa kenaikan upah berkaitan dengan produktivitas atau kinerja yang baik dari karyawan tersebut. Reward mempengaruhi kinerja karyawan secara signifikan (Prabu \& Wijayanti, 2016)

Menentukan bentuk reward yang akan diberikan kepada karyawan merupakan hal yang penting apabila reward system ingin berjalan efektif. Ada beberapa hal yang perlu diperhatikan dalam menentukan bentuk reward. Pertama, manajemen harus mengetahui apakah karyawan mendapatkan reward yang berkesan atau tidak. Upah adalah hal penting, tetapi reward adalah hal yang diinginkan dan dibutuhkan oleh karyawan. Ada sedikit keraguan jika upah adalah reward yang sangat penting. Reward harus dilihat dari perspektif yang luas yang berkaitan dengan karyawan dan termasuk beberapa hal seperti letak kantor, peralatan pendukung karyawan, tugas istimewa dan pengakuan informal.

Manajemen dari organisasi harus melihat reward dari sudut pandang karyawan. Bukan dari sudut pandang mereka sendiri. Manajemen beranggapan apabila mereka dapat memutuskan reward yang dibutuhkan dan diinginkan oleh karyawan. Sayangnya kurang tepat. Penelitian sebelumnya (dalam (Byars, L. L., \& Rue, 2004) menunjukkan jika karyawan merasa kurang adanya pengakuan sebagai alasan mereka keluar dari pekerjaannya. Survey sebelumnya (dalam (Byars, L. L., \& Rue, 2004), karyawan diminta untuk merangking job incentivenya dari paling 
utama. Hasil survey tersebut didapatkan jika ucapan terima kasih secara personal adalah hal yang utama, diikuti ucapan terima kasih secara tertulis dari atasan.

Masalah lain adalah kenyataan jika kebanyakan organisasi menawarkan mix of reward kepada semua karyawan. Penelitian menunjukkan jika banyak variable seperti umut, jenis kelamin, status perkawinan, jumlah tanggungan, dan masa kerha dapat mempengaruhi piliha karyawan untuk reward tertentu. Contohnya adalah karyawan yang sudah tua, biasanya lebih fokus dengan tunjangan pensiun daripada karyawan yang masih muda.

Hal lain yang dipertimbangkan dalam memilih tipe reward untuk penawaran adalah keuntungan intrinsic yang meningkat sebagai hasil dari reward. Manajemen dan karyawan hanya mempertimbangakn reward yang berwujud terkait dengan reward yang diberikan.

\section{Kesimpulan}

Berdasarkan penelitian yang sudah dilakukan oleh peneliti di PT Industri Kereta Api Indonesia (Persero) Madiun, didapatkan beberapa hasil. Intrinsic reward di PT INKA diwujudkan dalam bentuk Most Valuable Employee. Most Valuable Employee adalah event tahunan yang diberikan untuk mengapresiasi karyawan-karyawan yang mempunyai standar lebih dari yang sudah di tetapkan PT INKA. Extrinsic reward di PT INKA adalah tunjangan transport, tunjangan hari raya, tunjangan pendidikan, tunjangan jabatan, promosi dan insentif. 


\section{BIBLIOGRAFI}

Abdullah, R., Musa, Mushaireen, Zahari, Harnizam, Rahman, Razman, \& Khalid, Khazainah. (2011). The Study Of Employee Satisfaction And Its Effects Towards Loyalty In Hotel Industry In Klang Valley, Malaysia. International Journal of Business and Social Science, 2(3), 147-155.

Akbar, Febrian Nurtaneo. (2012). Pengaruh Motivasi Intrinsik dan Motivasi Ekstrinsik Terhadap Kinerja Karyawan Pada PT Perkebunan Nusantara XII Surabaya. Jurnal Ilmiah Mahasiswa FEB, 1(2).

Bustamam, Farah Liyana, Teng, Sze Sook, \& Abdullah, Fakhrul Zaman. (2014). Reward Management And Job Satisfaction Among Frontline Employees In Hotel Industry In Malaysia. Procedia-Social and Behavioral Sciences, 144(1), 392-402.

Byars, L. L., \& Rue, L. W. (2004). Human Resource Management. New York: McGraw-Hill.

Damayanti, Agiel Puji, Susilaningsih, Susilaningsih, \& Sumaryati, Sri. (2013). Pengaruh Kompensasi dan Motivasi Kerja Terhadap Kinerja Karyawan Perusahaan Daerah Air Minum (PDAM) Surakarta. Jurnal Pendidikan Ekonomi Universitas Sebelas Maret, 2(1), 13529.

Edirisooriya, Waruni Ayesha. (2014). Impact of rewards on employee performance: With special reference to ElectriCo. Proceedings of the 3rd International Conference on Management and Economics, 26(1), 311-318. Citeseer.

Gohari, Alireza, Eslamian, Saeid, Mirchi, Ali, Abedi-Koupaei, Jahangir, Bavani, Alireza Massah, \& Madani, Kaveh. (2013). Water Transfer As A Solution To Water Shortage: A Fix That Can Backfire. Journal of Hydrology, 491, 23-39.

Güngör, Pınar. (2011). The Relationship Between Reward Management System And Employee Performance With The Mediating Role Of Motivation: A Quantitative Study On Global Banks. Procedia-Social and Behavioral Sciences, 24, 1510-1520.

Hafiza, Nadia Sajjad, Shah, Syed Sohaib, Jamsheed, Humera, \& Zaman, Khalid. (2011). Relationship Between Rewards And Employee's Motivation In The Non-Profit Organizations Of Pakistan. Business Intelligence Journal, 4(2), 327-334.

Koencoro, Galih Dwi. (2013). Pengaruh Reward Dan Punishment Terhadap Kinerja (Survei Pada Karyawan PT. INKA (PERSERO) Madiun). Jurnal Administrasi Bisnis, 5(2).

Linz, Susan J., \& Semykina, Anastasia. (2011). Personality and performance: A comparative analysis of workers in transition economies. Personality and Individual Differences, 51(3), 293-301.

Luthan, Putri Lynna A. (2011). Pemodelan Peningkatan Produktivitas, Daya Saing Dan 
Kinerja Industri Konstruksi Pada Bangunan Bertingkat Terhadap Kinerja Waktu. In: Seminar Nasional Ke-3 FT. UISU, 26-29 April 2011, Medan.

Manullang, M. (2004). Dasar-dasar Manajemen. Yogyakarta: Gadjah Mada University Press.

Moorhead, Gregory, \& Griffin, Ricky W. (2013). Perilaku Organisasi: Manajemen Sumber Daya Manusia dan Organisasi. Jakarta: Salemba Empat.

Mulyadi \& Setyawan, J. (2001). Sistem Perencanan dan Pengendalian Manajemen. Yogyakarta: Salemba Empat.

Newman, Alexander, \& Sheikh, Abdullah Z. (2012). Organizational rewards and employee commitment: a Chinese study. Journal of Managerial Psychology.

Prabu, Aldila Saga, \& Wijayanti, Dewie Tri. (2016). Pengaruh penghargaan dan motivasi terhadap kinerja karyawan (Studi pada divisi penjualan PT. United Motors Center Suzuki Ahmad Yani, Surabaya). Jurnal Ekonomi Bisnis Dan Kewirausahaan, 5(2), 104-117.

Wirawan, Adhitomo, \& Afani, Ismi Nur. (2018). Pengaruh Reward dan Punishment terhadap Kinerja dan Motivasi Karyawan pada CV Media Kreasi Bangsa. Journal of Applied Business Administration, 2(2), 242-257. 